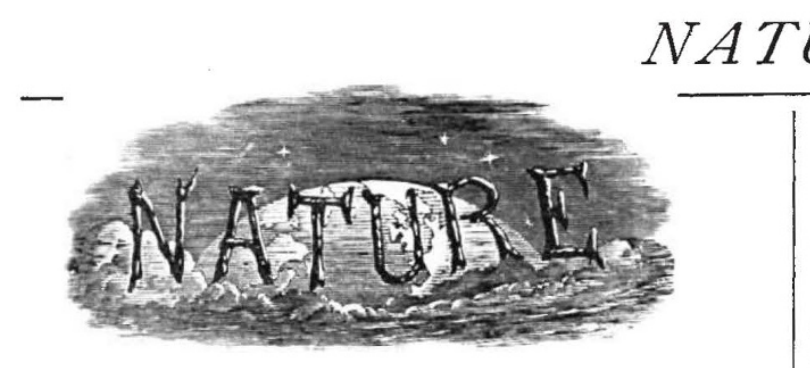

SATURDAY, NOVEMBER II, I922.

CONTENTS. PAGE

Technical'institutions and the Board of Education . 657 Internal Secretion. By Sir W. M. Bayliss, F.R.S. 658 The Origin of Worlds. By Dr. A. C. D. Crommelin 660 Reservoir and other Dams. By Dr. Brysson Cunningham.

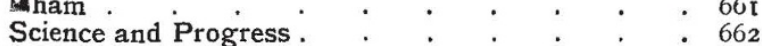

Our Bookshelf . . . . . . . . . 662

Letters to the Editor:-

The Isotopes of Selenium and some other Elements. -Dr. F. W. Aston, F.R.S.

Bohr's Model of the Hydrogen Molecules and their Magnetic Susceptibility.-Prof. Kôtarô Honda .

Gravity Observations in India.-R. D. Oldham,

F.R.S.
The Miraculous Draught of Fishes. -T. R. R. S.

Right Hon. Sir Herbert Maxwell, Bart.,

F.R.S. ; Dr. W. B. Drummond; Hy. Harries

On the Reality of Nerve Energy. - Prof. D. Fraser Harris

Habits of Echinus esculentus, -Richard Elmhirst .

Perseid Meteors in July 1592.- H. Beveridge

Skin Effect in Solenoids.-G. Breit

Colour Vision and Syntony.-H. S. Ryland

Mosaic Disease in Plants. - Kenneth M. Smith

Einstein's Paradox.-Rev. H. C. Browne; Prof. H. Wildon Carr

Waterspouts. - Dr. Willard J. Fisher :

Tables of the Incomplete Gamma-Function.-Prof. Karl Pearson, F.R.S.

The Nitrogen Industry. By Prof. C. H. Desch

The Thermal Basis of Gas Supply. By Prof. John W. Cobb.

Obituary :-

Prof. A. Crum Brown, F.R.S.
Prof. J. P. Kuenen. By Prof. H. Kamerlingh

Onnes, For. Mem. R.S.

Current Topics and Events

Our Astronomical Column.

The Origin of Atmospherics. By R. A. Watso 679

Watt

X-Ray Electrons. By Prof. A. O. Rankine . . 68I

Correlation of the Social Sciences . . . 682

The Effect of Deformation on the Ar I Change in Steels

Medical Education

The Chilian Earthquake

$\cdot \cdot \cdot 683$

University and Educational Intelligence . . . 684

Calendar of Industrial Pioneers . . . . . . 685

Societies and Academies . . . . 685

Official Publications Received : . . . . . 688

Diary of Societies . . . . .

Editorial and Publishing Offices:

MACMILLAN \& CO., LTD.,

ST. MARTIN'S STREET, LONDON, W.C.2.

\begin{abstract}
Advertisements and business letters should be addressed to the Publishers.
\end{abstract}

Editorial communications to the Editor.

Telegraphic Address: PHUSIS, LONDON.

Telephone Number: GERRARD 8830.

NO. 2768 , VOL. IIO]

\section{Technical Institutions and the Board of Education.}

THE Board of Education has issued a circular (I286) for the purpose of defining full-time teaching service within the meaning of the School Teachers (Superannuation) Act. The Board appears to find much difficulty in defining full-time teaching servicedifficulty which would not be shared, we think, by the average layman.

It would seem to us that there are two classes of teachers-those who have chosen teaching as their profession and have taken up full-time appointments under an Education Authority, and those who are known as visiting teachers or part-time teachers, and attend at their educational institutions only ir order to conduct the special courses for which they were appointed. Generally speaking, the latter individuals are members of some other profession and would not expect to be regarded as full-time teachers. We can believe that there may be a few border-line cases-but they would be relatively very few, and each case could be considered on its merits. But the Board of Education-or is it the Treasury? - cannot look at the matter in this broad light, and this circular is an attempt to define full-time teaching service. The circular indicates that the first essential for recognition of full-time teaching service should be a formal agreement between employer and teacher in which should be clearly set out the nature of the duties, whether they are wholly of a teaching character, the extent of the employer's claim upon the teacher's working hours, and the restrictions, if any, put upon the employment.

We should have thought that such an agreement would have been sufficient evidence of full-time teaching service, just as it would be sufficient evidence for any judge or jury. Indeed, it is even sufficient for the Board so far as head or assistant teachers on the ordinary staffs of elementary or secondary schools are concerned, but in the case of specialist teachers and of teachers in technical schools and colleges, many of which are of university rank, "it will be necessary to call ... for information as to the actual teaching hours as evidence of their full-time employment." Teachers in technical schools and colleges have a genuine cause for complaint here-not only because their agreement cannot be regarded by the Board as sufficient evidence in itself, but also because of the nature of the additional evidence to be demanded.

Full-time teaching service consists essentially of two component parts : actual teaching before a class, and the subsidiary duties entailed by actual teaching. The proportional value of these components depends, most 
obviously, upon the subject taught, upon the standard which is reached, upon the technicality of the subject, and upon the experimental preparation involved. Therefore it would be impossible for the Board to make any just assessment of the magnitude of the subsidiary duties entailed on a bare return of actual teaching hours. If the Board of Education is unable to accept an approved agreement as sufficient evidence of full-time service, then, in justice to the teachers of science and technology, it must have more information than would be given by a mere return of actual teaching hours.

The circular indicates that the specific preparation of lessons (as distinct from general study) would be regarded as a subsidiary duty entailed by actual teaching, and we would point out here that teachers of science and technology must spend a large amount of time in keeping in touch with modern developments in science, and with the even more rapid and more extensive developments of the applications of science to industry. The time absorbed to this end cannot be regarded fairly as general study of an independent kind; it cannot be considered as dissociated from the teaching service; and it cannot be described as non-essential.

The teacher of science and technology has a claim for very special consideration here, for, though we are prepared to admit that every teacher should and must spend time in general study and should keep in touch with modern developments, yet we cannot be expected to believe that the time which must be spent in keeping up with the development of, for example, Roman history, is comparable with that which must be spent in keeping in touch with the development of electrical engineering.

In this connexion we note with amazement that according to this circular (clause 7) research work will not be regarded as teaching service, and the time spent in research work would not be counted as teaching service for the purpose of the Superannuation Act. We can only hope that either our reading of the clause is wrong or that it has been badly phrased, and does not express the real intention of the Board. If the research work referred to is research work which a teacher is undertaking on behalf of some firm, and for which he is receiving remuneration, then it is quite reasonable to regard such work as private work and not as teaching service to the State. But if the clause means that all research work will be regarded as nonteaching service, then we must protest most emphatically in the interests of the State.

Is it not essential for teachers of science and technology to give a certain amount of attention to research work in order to keep in touch with modern developments? Are there not students doing research work NO. 2768 , VOL. I IO] in many of our technical institutions? Will the time spent by the teachers in these institutions in guiding and directing that work be regarded as of no service to the State? Surely that clause in the circular has been badly phrased : it is incredible that all research work in technical institutions should be banned, by order of the Board of Education! For many years the value of research by teachers has been impressed upon the governing bodies of our chief technical institutions, but if the Board holds that time spent upon such investigations, however stimulating the work may be to teacher or pupil, is to be excluded from the superannuation scheme as pensionable service, then the institutions will be thrown back to the state they were in twenty years ago.

We feel that this circular has been drawn up without sufficient consideration of what is involved in the teaching of scientific and technological subjects, and it would seem that there has not been sufficient regard for the special conditions of teachers of science and technology in our technical schools and colleges.

We are glad to note, however, that the circular has been sent out to local authorities, governing bodies, and others for their observations, and that the Board will not arrive at a final decision as to the application of the principles set out until these observations have been considered. We hope, therefore, to see very considerable amendment in the final form of the circular.

\section{Internal Secretion.}

Glands in Health and Disease. By Dr. B. Harrow. Pp. xv +2 r8. (New York: E. P. Dutton and Co., r922.) n.p.

Internal Secretion and the Ductless Glands. By Prof. Swale Vincent. Second edition. Pp. $\mathrm{xx}+422$. (London: E. Arnold and Co., I922.) 25s: net.

$7 \mathrm{HE}$ two books before us have not the same object 1 or scope, but they appear equally to fulfil the purpose intended. On the whole, they may be said, along with Sir E. Sharpey Schafer's "Endocrine Organs," to be the most useful books on the subject in the English language, apart from the encyclopædic "Endocrinology". edited by Llewellys Barker. While that of Dr. Harrow is of a somewhat popular nature, assuming comparatively little physiological knowledge on the part of the reader, Prof. Swale Vincent's book has the more ambitious aim of a scientific presentation of the facts definitely known on the subject. This latter has therefore rather the character of a work of reference, and will be found very useful in this way. It is naturally not so easy to read as Dr. Harrow's book, which presents an admirable, connected account of the 